\title{
The Influence of Perceived Organizational Support on Job Satisfaction with Employee Engagement as a Mediating Variable: Study on State Civil Apparatus (ASN) at Secretariat of Presidential Advisory Council
}

\author{
$1^{\text {st }} \mathrm{S}$ L Meisyara \\ Faculty of Administrative Science, \\ Universitas Indonesia \\ Jakarta, Indonesia \\ shelbyliriara@gmail.com
}

\author{
$2^{\text {nd }} F$ D Saragih \\ Faculty of Administrative Science, \\ Universitas Indonesia \\ Jakarta, Indonesia
}

\author{
$3^{\text {rd }}$ B Y Nugroho \\ Faculty of Administrative Science, \\ Universitas Indonesia \\ Jakarta, Indonesia
}

\begin{abstract}
The aim of this study is to investigate the relation between the perceived organizational support and job satisfaction by using employee engagement as a mediating variable. This research is conducted in Secretariat of Presidential Advisory Council. Furthermore, the quantitative approach is used in this research. The data is collected by distributing questionnaires to 62 respondents and analyzed through SPSS version 25 using the PROCESS. The result of this study indicate that POS has no direct effect on employee's job satisfaction and has an effect if it use employee engagement as a mediating variable. It was also found that employee engagement has a full mediator function between POS and job satisfaction. For this reason, the Secretariat of Presidential Advisory Council must pay attention to POS in the organization as one of the supporting factors to increase employee engagement and job satisfaction, which in turn will have an impact on the high performance of employees and the organization.
\end{abstract}

Keywords-Perceived organizational support, employee engagement, job satisfaction, state civil apparatus

\section{INTRODUCTION}

Public services are activities or series of activities in the framework of meeting service needs in accordance with statutory regulations for every citizen and resident of goods, services, and/or administrative services provided by public service providers [1]. Basically, the quality of public services can be a measure of government performance, both the central and regional governments and this can be assessed and felt directly by the community. For this reason, efforts that an organization can undertake in order to provide maximum service quality, a healthy work organization is required which is supported by qualified and competent apparatus human resources in the administration of the state and development.

Many things can be done by an organization in order to be able to improve the quality of human resources, one of which is by raising employee job satisfaction. Researchers have conducted literature analyses of many studies conducted from 1986 to 2014, with the results of research studies which proved that organizations could foster employees' job satisfaction by eliciting an employee engagement, as well as by fostering good perceived organizational support (POS) for employees [2],[3].

The Secretariat of the Presidential Advisory Council (Setwantimpres) is an organizational unit within the Ministry of State Secretariat chaired by the Secretary of the Presidential Advisory Board (Seswantimpres), which is under and responsible to the Presidential Advisory Council (Wantimpres) and it is administratively coordinated by the Minister of State Secretary [4], and it has the task of providing technical and administrative support services to the Wantimpres [5].

Government Institution Performance Accountability Report, which is known as LAKIP, is one of the forms of accountability for the implementation of tasks that function, among others, as a performance appraisal tool, a form of accountability of the implementation of tasks and functions of government agencies and a form of transparency, as a report of accountability to the public, it can also be a control tool and a booster for the improvement of the performance of each organizational unit within government agencies [6]. Based on the 2015 to 2019 Setwatimpres LAKIP, the Setwantimpres has always succeeded in achieving the strategic objectives of the organization, where the realization of performance has always reached $100 \%$, with an increase in the achievement of the level of satisfaction of the Wantimpres every year [6]. This achievement showed that the Chairperson and Members of Wantimpres were satisfied with every service and performance made by the Secretariat. 
However, it is necessary to note one factor, that is, the factor of employee job satisfaction which seemed to be less satisfactory and it became a concern for the organization. Lacking of tools to measure the level of job satisfaction of employees in the Setwantimpres was one of the obstacles encountered and, therefore, organizations could not find out whether employees have felt job satisfaction or have provided their best performance to help achieve organizational goals. If seen from several points in the instrument of job satisfaction measurement which were introduced, there are still many things that have not been implemented by Setwantimpres in the effort of improving employee job satisfaction, and one of them was employee satisfaction with the leadership [7],[8],[9]. The concern of the leadership in terms of delivering information to the employees of the Secretariat was still lacking. This could be seen from the lack of socialization of disciplinary regulations, information delays, or even not delivering important announcements that should be informed by the Personnel Subdivision to the Civil Servants (PNS) of Setwantimpres, such as information related to the adjustment/equalization test for employees who have completed formal education or information related to scholarship program offers. In addition, another matter that needs to be considered by the Secretariat is the provision of organizational support to employees, in which the organization is still considered not paying enough attention to criticism or suggestions made by employees. This can be seen from the unavailability of a forum for making complaints or criticism and suggestions provided for employees who are at the lowest position to the leadership or organization.

In the light of some descriptions made above, this research study will discuss further the effect of perceived organizational support on job satisfaction with employee engagement as a mediating variable on State Civil Apparatus (ASN) at the Secretariat of Presidential Advisory Council. This study aims to determine whether State Civil Apparatus at Setwantimpres, who are in this case are civil servants, have got a sense of job satisfaction and how employees' perceptions of organizational support at Setwantimpres are, and whether employee engagement is one of the factors mediating the relationship between perceived organizational support and job satisfaction with State Civil Apparatus at Setwantimpres.

\section{THEORY AND HYPOTHESIS DEVELOPMENT}

\section{A. Perceived Organizational Support (POS)}

POS is the employee's perception of the values and contribution or support of the organization to its employees and whether the organization cares about employee wellbeing [10]. Survey of Perceived Organizational Support (SPOS), and it is a questionnaire consisting of 36 question items, which until now, is still often used by other researchers, both in the original questionnaires with 36 question items or in a simple modified form. All statements contained in the SPOS are intended as assessment and evaluation materials for the organization which are aimed to find out how employees' satisfaction is as members of the organization, employee performance, anticipation of employee values in the future, appreciation or appreciation for the organization for the performance made employees, organizational considerations of targets, input, and suggestions of employees, fairness in the provision of salaries, job enrichment, utilization of talents and abilities of employees, employee satisfaction with work, and employee well-being. In addition, there are statements about what type of treatment by the organization is expected by the employees to treat them such as willingness to help when they are faced with problems, replacing old employees with new employees with lower salaries, responding to employee complaints, mistakes, poor performance, performance improvement, requests for change environmental conditions, special requests, choices to resign from the organization, failure to complete tasks on time, employee retention, policies for re-hiring employees after being laid off, and opportunities for promotion,[12].

\section{B. Employee Engagement}

The term "engagement" may refer to the presence of psychological conditions when individuals occupy or carry out roles as members in organizations [13]. In addition, employee engagement define as a positive state of mind, a feeling of satisfaction and a sense of engagement to work that is marked by enthusiasm (vigor), dedication, and absorption [14]. They elaborate further that engagement is not a condition that arises suddenly and is momentary, but is an affective-cognitive state that is persistent and pervasive into individual employees and does not only focus on certain objects, events, individuals, or behaviors [14].

\section{Job Satisfaction}

Job satisfaction is a positive emotion that occurs as a result of the value held by employees related to work, work environment, and social interaction and as a result of employee's assessment of their expectations of work and the actual work environment [13],[14]. Of several existing job satisfaction theories, there are also many other measurement instruments which can be used to measure job satisfaction. There are 4 facet measurement scales to measure job satisfaction [9], namely, the Job Satisfaction Survey (JSS) [8], the Job Descriptive Index (JDI) [7], the Minnesota Satisfaction Questionnaire (MSQ) [15], and the Job Diagnostic Survey (JDS) [16]. And, there are two other measurement scales, but these scales are used to measure job satisfaction with general views, not divided into question sections, namely, the Job in General Scale (JIG) [9],[17] and Michigan Organizational Assessment Questionnaire Satisfaction Subscale [9],[18]. In JDI, that there are aspects that can bring about a sense of job satisfaction, namely, work, pay, promotion, supervision, and coworkers [9].

\section{POS, Employee Engagement, and Job Satisfaction Relationship}

In journal titled "A Meta-Analysis of the Relationship between Perceived Organizational Support and Job Outcomes: 20 Years of Research" show that the study was carried out for 20 years (1986-2006) by reviewing various literature related to the relationship between POS and various job outcomes [2]. The results of the study show that POS has a positive and strong (significant) effect on job satisfaction and organizational commitment; has a positive 
and moderate (moderate) effect on performance, and a negative and strong (significant) effect on intention to leave. In addition, there was a research study conducted by collecting literature from 2007 to 2014 and aimed to see the latest developments of the previous literature [3]. The results show that there are 5 main things on organizational members that can be influenced by POS, namely, employee engagement, job satisfaction, organizational commitment, organizational citizenship behavior (OCB), and turnover intention. The results of the research study show that POS has a strong and positive influence on employee engagement, job satisfaction, and organizational commitment, but they do not have strong and positive influence on OCB and turnover intention [3].

Thus the above literature leads us to formulate the following research hypotheses:

H1 : Perceived organizational support has a positive influence on job satisfaction

H2 : Perceived organizational support has a positive influence on employee engagement

H3 : Employee engagement has a positive influence on job satisfaction

H4 : Employee engagement mediates the relationship between perceived organizational support and job satisfaction.

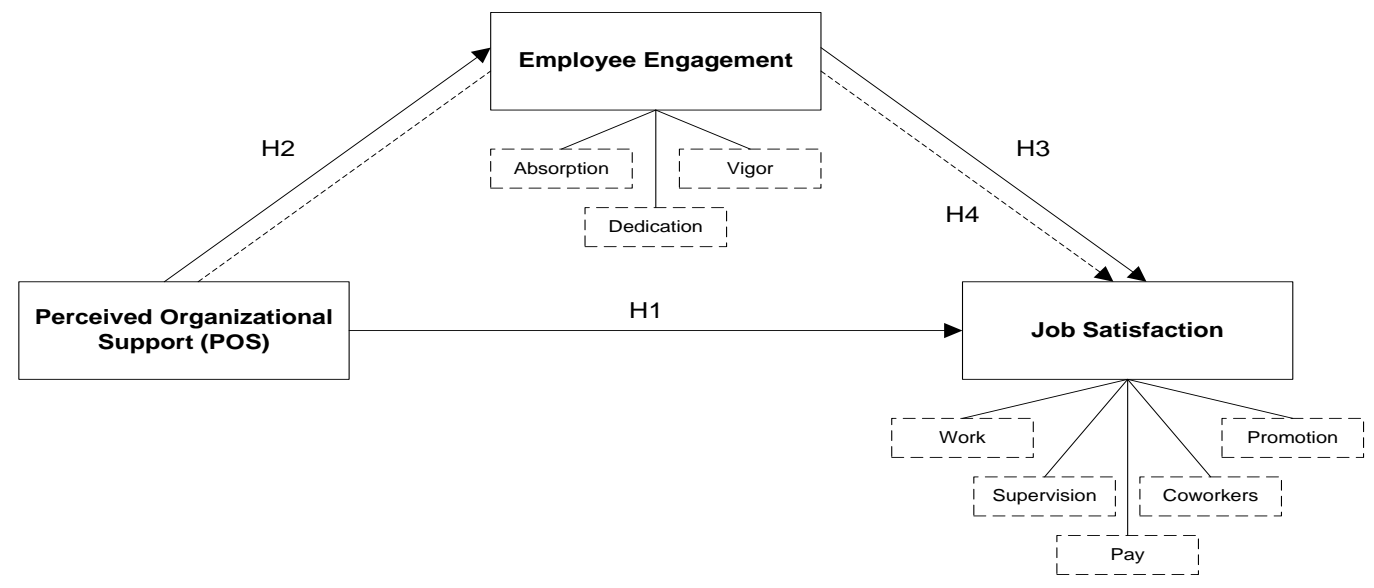

Fig. 1. Research Frame Work.

Source: Researcher Processing

\section{DATA COLLECTION AND METHODOLOGY}

Data Collection and Measurement Scales: As the study aims to find the relationship between POS and job satisfaction through the mediation of employee engagement on civil servants at the Secretariat of Presidential Advisory Council. A survey approach, with questionnaires, adopted from multiple studies, was used as a tool for data collection. This study uses saturation sampling, in which the study sample uses the entire population due to the limited number of populations to be studied, that is, a sum of 62 civil servants working at the Secretariat. Five-point Likert Scale, was used to measure the study variables. For POS, 8-item scale was used and it called Survey of Perceived Organizational Support (SPOS) [21]. Moreover, the 17-item employee engagement scale was used and called The Utrecht Work Engagement Scale (UWES), and having 3 dimensions: absorption (6 items), vigor (5 items ), and dedication (6 items) [22]. Lastly, the 24-item job satisfaction scale, called the Descriptive Index
Job (JDI), and having 5 dimensions: work ( 4 items), pay (4 items) , promotion (4 items), supervision (7 items), and coworkers (5 items) [7],[9]. Data analysis was done by using Bootstrapping method through PROCESS on SPSS ver.25 [23].

\section{RESULT}

A. Respondents' Demographic Profile and Descriptive Statistic

Table 1 shows that a sum of 62 civil servants in Setwantimpres who were also respondents in this study, consisting of 31 male employees $(50 \%)$ and 31 female employees $(50 \%)$. In terms of age, the majority of civil servants in Setwantimpres are aged between 31 to 40 years, amounting 28 employees (45.16\%), with the most recent education amounting to 31 employees (50\%), namely with a bachelor's degree. In terms of position, the majority of civil servants in the Setwatimpres are as staff, namely, amounting to 36 employees (58.06\%), and 27 employees $(43.55 \%)$ with years of service of 1 to 5 years. 
TABLE 1. RESPONDENTS’ DEMOGRAPHIC PROFILE.

\begin{tabular}{|c|c|c|c|c|}
\hline No. & Characteristics & Category & Freq. & $\%$ \\
\hline \multirow[t]{2}{*}{1} & \multirow[t]{2}{*}{ Sex } & 1. Male & 31 & 50,00 \\
\hline & & 2. Female & 31 & 50,00 \\
\hline \multirow[t]{4}{*}{2} & \multirow[t]{4}{*}{ Age } & 1. $20-30$ years & 20 & 32,26 \\
\hline & & $2.31-40$ years & 28 & 45,16 \\
\hline & & $3.41-50$ years & 9 & 14,52 \\
\hline & & 4. $>50$ years & 5 & 8,06 \\
\hline \multirow[t]{4}{*}{3} & \multirow[t]{4}{*}{ Last Education } & 1. Senior High School/Equivalent & 2 & 3,23 \\
\hline & & 2. D3/Equivalent & 9 & 14,52 \\
\hline & & 3. S1/Equivalent & 31 & 50,00 \\
\hline & & 4. S2 & 20 & 32,26 \\
\hline \multirow[t]{4}{*}{4} & \multirow[t]{4}{*}{ Position } & 1. Staff & 37 & 59,68 \\
\hline & & 2. Chiefs of Sub-Division & 18 & 29,03 \\
\hline & & 3. Head of Division & 5 & 8,06 \\
\hline & & 4. Head of Bureau & 2 & 3,23 \\
\hline \multirow[t]{3}{*}{5} & \multirow[t]{3}{*}{ Years (Length) of Service } & $1.1-5$ years & 27 & 43,55 \\
\hline & & 2. $6-10$ years & 13 & 20,97 \\
\hline & & 3. $11-14$ years & 22 & 35,48 \\
\hline
\end{tabular}

Source: Researcher Processing

In addition to demographic table, descriptive analysis table can also be used to describe the entirety of each variable. In this section, the researcher conducts a descriptive analysis to find out the mean, maximum, and minimum, for each indicator and find the grand mean value for each variable. The following are the results of the researcher's descriptive analysis using Ms. Excel 2007:

TABLE II. SCORE RANGE OF DESCRIPTIVE ANALYSIS

\begin{tabular}{|c|c|c|}
\hline Variable & Dimension & Mean \\
\hline \multirow{3}{*}{ POS } & - & 2,82 \\
\hline \multirow{4}{*}{ Employee Engagement } & Vigor & 3,38 \\
\cline { 2 - 3 } & Dedication & 3,56 \\
\cline { 2 - 3 } & Absorption & 3,40 \\
\hline \multirow{3}{*}{ Job Satisfaction } & Work & 3,73 \\
\cline { 2 - 3 } & Pay & 3,94 \\
\cline { 2 - 3 } & Promotion & 3,73 \\
\cline { 2 - 3 } & Supervision & 3,65 \\
\cline { 2 - 3 } & Coworkers & 4,14 \\
\hline
\end{tabular}

Source: Researcher Processing

The results of the descriptive analysis shown in Table 2 , show that POS has a value of 2.82 out of a maximum value of 5.00, where this value is still relatively low. However, on employee engagement and job satisfaction variables, the table shows a pretty good value for both variables, namely, 3.45 (a grand mean of 3 dimensions of employee engagement) and 3.84 (grand mean of 5 dimensions of job satisfaction). This shows that the employees of Setwantimpres feel that the support provided by the organization to its employees still needs to be increased. And it can also be seen that although the POS value shows low results, the value for employee engagement and job satisfaction shows good results. This is made possible by other factors that influence the emergence of a sense of engagement and satisfaction within the employees themselves.

A. Hypotheses Testing

In table 3 , it is depicted that there is a positive and significant effect between POS and employee engagement. This is indicated by a coefficient of 0.8449 and $p<0.05$ (H2 is supported). A positive and significant effect is also seen in the relationship between employee engagement and job satisfaction, with coefficient value of 0.7261 and $p<0.05$ (H3 is supported). The following are the results of research study data processing using SPSS ver.25: 
TABLE III. THE RELATIONSHIP BETWEEN POS, EMPLOYEE ENGAGEMENT, AND JOB SATISFACTION

\begin{tabular}{|c|c|c|c|c|c|c|}
\hline \multirow{2}{*}{ Variable } & \multicolumn{3}{|c|}{ Employee Engagement (M) } & \multicolumn{3}{|c|}{ Job Satisfaction (Y) } \\
\hline & Coeff & SE & $\mathbf{p}$ & Coeff & SE & $\mathbf{p}$ \\
\hline $\operatorname{POS}(\mathrm{X})$ & 0,8449 & 0,145 & 0,000 & 0,2045 & $\begin{array}{r}0,25 \\
7\end{array}$ & 0,428 \\
\hline Employee Engagement (M) & - & - & - & 0,7261 & $\begin{array}{r}0,18 \\
2\end{array}$ & 0,000 \\
\hline
\end{tabular}

Source: Data Processing Using SPSS

Furthermore, in Table III, it can be seen that the coefficient value between the POS variable and job satisfaction is -0.2045 with $\mathrm{p}>0.5$ and in Table IV, the total effect score is 0.4089 , with the Lower Level Confidence
Interval (LLCI) namely, -0.0494 and Upper Level Confidence Interval (ULCI) of 0.8673 . This value indicates that overall, POS does not have a direct influence on job satisfaction felt by employees (H1 is not supported).

TABLE IV. THE RELATIONSHIP BETWEEN POS AND JOB SATISFACTION THROUGH EMPLOYEE ENGAGEMENT AS MEDIATOR

\begin{tabular}{|c|c|c|c|c|}
\hline \multicolumn{5}{|c|}{ *Total Effect of $X$ on $Y$ : } \\
\hline Effect & se & $\mathbf{p}$ & LLCI & ULCI \\
\hline 0,4089 & 0,2291 & 0,0794 & $-0,0494$ & 0,8673 \\
\hline \multicolumn{5}{|c|}{ *Indirect Effect(s) of $\mathrm{X}$ on $\mathrm{Y}$ : } \\
\hline Variable & Effect & BootSE & BootLLCI & BootULCI \\
\hline $\begin{array}{l}\text { Employee } \\
\text { Engagement (M) }\end{array}$ & 0,6135 & 0,2492 & 0,1909 & 1,157 \\
\hline \multicolumn{5}{|c|}{ *Completely Standardized Indirect Effect(s) of X on Y: } \\
\hline Variable & Effect & BootSE & BootLLCI & BootULCI \\
\hline $\begin{array}{l}\text { Employee } \\
\text { Engagement (M) }\end{array}$ & 0,3368 & 0,1157 & 0,1142 & 0,5587 \\
\hline
\end{tabular}

Then, in Table 4, the mediating effect can also be seen in the indirect effect table which shows the results of the employee engagement variable, with a value in the effect column of 0.6135 , with a Bootstrap Lower Level of Internal Confidence (BootLLCI) of 0.1909 and BootULCI of 1 , 1157.

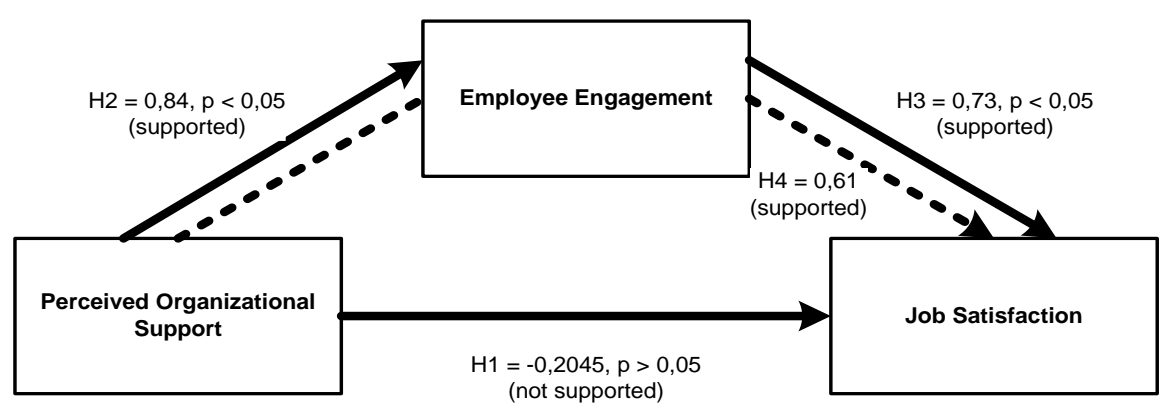

Fig. 2. Research Frame Work

Source: Data Processing Using SPSS

This result can mean that the effect score owned by the employee engagement variable is in the BootLLCI and BootULCI range without passing the value of 0 [23], so that it can be concluded that employee engagement has a mediating effect on the relationship between POS and job satisfaction and it is full mediation (H4 is supported). The result of the simple mediation model of this research is presented in Figure 2.

\section{DISCUSSION AND CONCLUSION}

\section{A. The Effect of POS on Job Satisfaction}

It was found that POS did not have a direct effect on job satisfaction of employees of the Setwantimpres (H1 is not supported). The low POS value in this study, is the picture of what is felt by the Setwantimpres civil servants related to the support from the organization. However, the low employee appraisal of POS does not have any influence or effect on employee job satisfaction. This is made possible by other factors which are considered to be more influential in generating and increasing employee job satisfaction, such as coworkers $($ mean $=4.14)$ or salary earned $($ mean $=$ 3.94). The results of a similar study, which proves the insignificant role of POS on job satisfaction felt by employees in the organization [24]. The study shows that there is an effect of POS on job satisfaction, but it is not significant, which is only $1 \%$. This was made possible 
because there were other factors that played roles in influencing employee job satisfaction [24].

\section{B. The Effect of POS on Employee Engagement}

The results of the study show that POS has a positive and significant influence on employee engagement in the Setwantimpres (H2 is supported). One example is when an organization pays more attention to its employees, among others, by providing a forum or a means of to making criticism, suggestions, or complaints to the organization, and the organization can provide feedback from all incoming inputs and complaints, and in this way it certainly can increase the sense or feeling of employee engagement to the organization. Employees will feel being valued and their roles are needed by the organization, so a sense of ownership will emerge which will ultimately foster a sense of job satisfaction. Some other researchers also found similar results, where POS was proven to have a positive influence on employee engagement. And, for research with positive but not significant results on the relationship between POS and employee engagement, it may be caused by the influence of other factors other than POS [2],[3],[25],[26],[27],[28],[29],[30].

\section{The Effect of Employee Engagement on Job \\ Satisfaction}

The results of this research study show that employee engagement has a positive and significant effect on the job satisfaction of employees in the Secretariat (H3 is supported). Employee engagement can certainly increase job satisfaction, and one example of this can be seen from the results of descriptive analysis. All dimensions of the employee engagement variable show a good value. It can be assumed that the Secretariat employees have already got a sense of engagement to their work and organization. The existence of this engagement, of course, can foster and also increase the sense of employee job satisfaction, which is characterized by the results of descriptive analysis of all dimensions of job satisfaction, which shows a higher value compared to the value on the dimensions of employee engagement. It can also be concluded that the high value of employee engagement can also affect high job satisfaction of the Secretariat employees. Some figures who also have similar research study results, which stated that there is a positive and significant relationship between employee engagement and job satisfaction, where high employee engagement can also affect employee job satisfaction [25],[26],[27],[28].

D. The Effect of Employee Engagement as a Mediating

Variable on the Relationship of POS and Job

Satisfaction

The results of the study show that employee engagement has a mediating role in the relationship between POS and job satisfaction and it is full mediation (H4 is supported). This explains that POS has a positive and significant influence on the job satisfaction of the employees of the Setwantimpres, when mediated by employee engagement variables. And, it can also be seen that there is no direct influence between the POS relationship with job satisfaction. The results of this study are also supported by other researcher who state similar research results, in which the employee engagement variable has the role of full mediator, which shows that employee engagement mediates fully, and it is positive, and is significant in the relationship between POS and PO Fit towards commitment of the organization and job satisfaction of employees in the organization [27]. [25] also shows the results of research in which employee engagement has a partial mediating role in the relationship between POS and job characteristics and job satisfaction.

Of the results of the analysis and discussion made by researcher, and based on the reviews of previous studies, it can be seen that the support of the organization given by the Setwantimpres to its employees, is still considered and perceived low by the majority of employees. This is indicated by the low value of the results of analysis in the POS variable. However, again, it can be seen that the POS has a positive influence on employees' engagement at the Setwantimpres, and it can be interpreted that by increasing the POS, the Setwantimpres will also be able to foster and increase the employees' engagement and job satisfaction to their work and organization. When employees' job satisfaction is felt or considered to have achieved what is expected, this will certainly have a good effect on employee performance as well, so that employees can provide quality services to all Wantimpres Members.

\section{LIMITATION AND FUTURE RECOMMENDATIONS}

There are some limitations to this study, among others, as follows: 1) the measurement instrument uses a Likert scale with a measurement scale of 1-5. This research limitation may cause the tendency of respondents to choose the middle scale; 2) Research variables are only limited to POS, employee engagement, and job satisfaction. To examine employees' job satisfaction factors, research was limited to the POS and employee engagement variables. Meanwhile, many other factors that can affect employees' job satisfaction can be investigated; 3) The object of research is limited to civil servants working in the Setwantimpres, with too small research sample and, therefore, the results of the study will not be able to describe the situation in civil servants in general.

With the limitations of research mentioned above, it is expected that a further research can pay attention to these limitations by eliminating or lifting them into further research which is better, so that its results will be able to describe the general situation more accurately. However, despite the limitations, this research study has provided some evidence that organizations must pay attention to POS in the organization as a supporting factor in order to increase employee engagement and job satisfaction, which in turn will have an impact on high performance of employees and organizations.

\section{REFERENCES}

[1] Law No 25 of 2009 concerning Public Services

[2] Riggle R J, Edmondson D R and Hansen J D 2009 A metaanalysis of the relationship between perceived organizational support and job outcomes: 20 years of research Journal of Business Research 62(10) pp 1027-30

[3] Ahmed I, Nawaz M M, Ali G and Islam T 2015 Perceived organizational support and its outcomes: a meta-analysis of latest 
available literature Management Research Review 38(6) pp 62739

[4] Presidential Regulation No 10 of 2007 concerning the Work Procedures of the Presidential Advisory Council and the Secretariat of the Presidential Advisory Council

[5] Regulation of Minister of State Secretary No 2 of 2007 concerning the Organization and Work Procedures of Secretariat of Presidential Advisory Council

[6] Presidential Secretariat Performance Report 2019

[7] Smith P C, Kendall, L M and Hullin C L 1969 Measurement of satisfaction in work and retirement Chicago IL Rand McNally

[8] Spector P E 1985 Measurement of human service staff satisfaction: development of the Job Satisfaction Survei American Journal of Community Psychology 13 pp 693-713

[9] Spector P E 1997 Job satisfaction: application, assessment, causes, and consequences USA California: Sage Publication Inc

[10] Rhoades L and Eisenberger R 2002 Perceived organizational support: a review of the literature Journal of Applied Psychology 87(4) pp 698-714

[11] Eisenberger R, Huntington R, Hutchison S and Sowa D 1986 Perceived organizational support Journal of Applied Psychology 71 pp 500-7

[12] Shahab S N 2017 Pengaruh persepsi dukungan organisasi dan kepuasan kerja keseluruhan terhadap intensi mengundurkan diri yang dimediasi oleh keterikatan pegawai di PT XYZ Thesis Depok: Faculty of Economics and Business Universitas Indonesia

[13] Locke E A 1976 The nature and causes of job satisfaction In M D Dunnette (Ed) Handbook of industrial and organizational psychology Chicago IL Rand McNally pp 1297-343

[14] Kahn W A 1990 Psychological conditions of personal engagement and disengagement at work Academy of Management Journal 33 pp 692-724

[15] Weiss D J, Dawis R V, England G W and Lofquist L H 1967 Manual for the Minnesota Satisfaction Questionnaire Minnesota Studies in Vocational Rehabilitation Minneapolis University of Minnesota Industrial Relations Center 22

[16] Hackman J R and Oldham G R 1975 Development of the Job Diagnostic Survey Journal of Applied Psychology 60 pp 159-70

[17] Ironson G H, Smith P C, Brannick M T, Gibson W M and Paul K B 1989 Construction of a job in general scale: A comparison of global, composite, and specific measures Journal of Applied Psychology 74 pp 193-200

[18] Camman C, Fichman M, Jenkins D and Klesh J 1979 The Michigan Organizational Assessment Questionnaire Unpublished manuscript University of Michigan Ann Arbor

[19] Schaufeli W B, Salanova M, Gonzalez Roma V and Bakker A B 2002 The measurement of engagement and burnout: a two sample confirmatory factor analytic approach Journal of Happiness Studies 3 pp 71-92

[20] Celik $\mathrm{S}$ et al 2015 Relationship between ethical leadership, organizational commitment, and job satisfaction at hotel organizations Ege Academic Review 15(1) pp 53-63

[21] Rhoades L, Eisenberger R and Armeli S 2001 Affective commitment to the organization: the contribution of perceived organizational support Journal of Applied Psychology 86 pp 82536

[22] Schaufeli W B and Bakker A B 2010 Defining and measuring work engagement: Bringing clarity to the concept Work Engagement: A handbook of essential theory and research pp 1024

[23] Hayes A F 2013 Introduction to mediation, moderation, and conditional process analysis: a regression based approach New York The Guilford Press

[24] Dewi R S 2016 Peranan perceived organizational support terhadap kepuasan kerja Jurnal Ecopsy 2(3)

[25] Saks M A 2006 Antecedents and concequences of employee engagement Journal of Managerial Psychology 21(7) 600-19
[26] Nusantria S 2012 Employee engagement: anteseden dan konsekuensi Thesis Semarang Faculty of Economics and Business Universitas Diponegoro

[27] Biswas S and Bhatnagar J 2013 Mediator analysis of employee engagement: role of perceived organizational support, P-O fit, organizational commitment, and job satisfaction Vikalpa 38(1)

[28] Hasan S, Hassan M, and Shoaib M 2014 Measuring the impact of perceived organization support, psychological empowerment and rewards on employees' satisfaction: testing the mediating impact of employee engagement World Applied Science Journal 30(5) pp 652-60

[29] Shacklock et al 2014 The role of support antecedents in nurses' intention to quit: the case of Australia Journal of Advanced Nursing 70(4) pp 811-22

[30] Mujiasih E 2015 Hubungan antara persepsi dukungan organisasi (perceived organizational support) dengan keterikatan karyawan (employee engagement) Jurnal Psikologi Undip 14(1) pp 40-51 